DOI: 10.12731/wsd-2017-1-115-130

УДК 631.6:502.131

\title{
ЭКОСИСТЕМНЫЕ ПОДХОДЫ К ФУНКЦИОНИРОВАНИЮ ОРОСИТЕЛЬНЫХ СИСТЕМ
}

Ольгаренко В.И., Ольгаренко И.В., Ольгаренко В.Иг.

В статье изложены новые методологические подходы по оптимизачии процесса функиионирования оросительных систем, которые прошли широкую производственную проверку на оросительных системах Северного Кавказа и обоснованы с позищий ландшафтного подхода и на основе развития законов техники, кибернетики, экологии и экономико-математических методов. Предложен методологический подход, который даёт возможность рассматривать систему как многофакторную, замкнутую с регулируемыми антропогеннылми воздействиями на природную среду, что позволило разработать модель оросительной системы как объекта управления с учётом экологических требований и воздействий на неё природных и управляемых факторов, а также факторов оптимизации. Определена классификация, необходимая для оперативного планирования и управления орошением, включающая информачионно-справочную, сезонную и оперативную информацию. Совершенствование процесса планирования и управления орошением обеспечивается моделью прогноза, состоящей из блоков управления информационной базой и пространственно-временной оптимизации.

Ключевые слова: динамика; функиии; мелиоративная деятельность; признаки; эксплуатация; агроландшафт; имитационное моделирование; система; комплекс; оптимизация; природная среда.

\section{THE ECOSYSTEM APPROACHES TO THE OPERATION OF IRRIGATION SYSTEMS}

\section{Olgarenko V.I., Olgarenko I.V., Olgarenko V.Ig.}

The article presents a new methodological approaches to optimize the functioning processes of irrigation systems that have been passed a wide industrial verification in irrigation systems of the North Caucasus and proved 
from the standpoint of the landscape approach and on the basis of the laws of the technics, cybernetics, ecology and economic and mathematical methods. The methodological approach that has been proposed allows to consider the system as a multifactorial, closed with adjustable anthropogenic impacts on the environment, which allowed to develop a model of the irrigation system as a management object, taking into account environmental considerations and impacts on it natural and controllable factors, as well as the optimization factors. Determined classification which is required for operational planning and management of irrigation, including information and referral, seasonal and operational information. Improved planning and management process ensures of the irrigation forecast model, consisting of a control unit information base and the space-time optimization.

Keywords: dynamics; functions; reclamation activities; evidence; operation; agrolandscape; simulation modeling; system; complex; optimization; natural environment.

В статье изложены новые методологические подходы по оптимизации процесса функционирования оросительных систем, которые прошли широкую производственную проверку на оросительных системах Северного Кавказа и обоснованы с позиций ландшафтного подхода и на основе развития законов техники, кибернетики, экологии и экономико-математических методов. Предложен методологический подход, который даёт возможность рассматривать систему как многофакторную, замкнутую с регулируемыми антропогенными воздействиями на природную среду, что позволило разработать модель оросительной системы как объекта управления с учётом экологических требований и воздействий на неё природных и управляемых факторов, а также факторов оптимизации. Определена классификация, необходимая для оперативного планирования и управления орошением, включающая информационно-справочную, сезонную и оперативную информацию. Совершенствование процесса планирования и управления орошением обеспечивается моделью прогноза, состоящей из блоков управления информационной базой и пространственно-временной оптимизации.

\section{Цель}

Обосновать современную концепцию мелиоративной деятельности, опирающуюся на принципы устойчивого развития, которая должна ориентироваться не только на получение высоких и стабильных урожаев сельскохозяйственных культур, эффективное использование интегральных 
ресурсов, но и на создание благоприятной экологической обстановки в агроландшафтах.

\section{Материалы и методы}

Прогресс в развитии мелиоративной науки и практики, анализ научно-технических материалов, многолетние производственные исследования по эффективности функционирования мелиоративных систем в различных почвенно-климатических зонах Северного Кавказа, позволил разработать новые методологические подходы к понятию сущности мелиораций и в том числе мелиоративных систем с позиций ландшафтного подхода и на основе законов развития техники, кибернетики, в том числе методов системного анализа, экологии, экономико-математических методов $[1,2,7,17]$.

Исходя из вышесказанного, мелиоративная деятельность - это процесс, обеспечивающий с одной стороны, необходимый уровень продуктивности агроэкосистем, с другой - устраняющий негативное воздействие антропогенной нагрузки на природную среду и обеспечивающий достижение динамического равновесия кругооборота вещества и энергии уже на более интенсивном, по сравнению с природными экосистемами, уровне при увеличении скорости и объёма биологического кругооборота.

Ретроспективный анализ конструкций мелиоративных систем и функции их жизнедеятельности на основе законов стадийного развития техники $[3,4,18]$, а так же сущности метода функционально-структурного анализа, позволил установить динамику развития мелиоративных систем во временном аспекте, начиная с IV тысячелетия до н. э., а также их основные стандартные функции (табл. 1). Прежде всего, мелиоративная система функционирует в составе многофакторного природного комплекса, является его составной частью, проявляет свои специфические функции в процессе взаимодействия с природной средой и по своей сути является сложным природно-техническим объектом, составной частью агроландшафта $[6,9,13$, $14,19]$. Поэтому, на экологически сбалансированных мелиоративных системах, кроме четырёх стандартных функций, характерных для технических природных объектов - технологической, энергетической, планирования и управления, существует пятая функция - регулирования взаимодействия с природной средой $[5,8]$. Наличие данной функции указывает на отличительные особенности экологически сбалансированных мелиоративных систем за счёт усиления их экологической ориентации, динамичности систем, активизации деятельности по целенаправленному регулированию взаимодействия систем с природной средой в режиме оптимизации и в том числе 
по оптимальному расходованию всех видов ресурсов, повышении роли и значения процесса эксплуатации, обоснования основных принципов функционирования экологически сбалансированных систем.

Таблица 1.

Динамика развития мелиоративных систем и их функций

\begin{tabular}{|c|c|c|c|c|}
\hline \multirow{3}{*}{$\begin{array}{c}\text { Функ- } \\
\text { ции }\end{array}$} & \multicolumn{4}{|c|}{ Поколения мелиоративных систем и их функции } \\
\hline & $\mathrm{I}$ & II & III & IV \\
\hline & $\begin{array}{l}\text { IV-II тысячеле- } \\
\text { тие до н.э. }\end{array}$ & $\begin{array}{c}\text { II тысячелетие } \\
\text { до н.э. - начало } \\
\text { XX века }\end{array}$ & $\begin{array}{l}\text { Начало XX века - } \\
90 \text { годы XX века }\end{array}$ & $\begin{array}{c}90 \text { годы XX века - } \\
\text { начало XXI века }\end{array}$ \\
\hline $\begin{array}{l}\text { Техно- } \\
\text { логиче- } \\
\text { ская }\end{array}$ & $\begin{array}{l}\text { Использование } \\
\text { примитивных } \\
\text { приемов по во- } \\
\text { дозабору, транс- } \\
\text { портирующей, } \\
\text { распределитель- } \\
\text { ной и отводящей } \\
\text { сетей }\end{array}$ & $\begin{array}{l}\text { Поиск, разработка } \\
\text { и применение } \\
\text { инженерных } \\
\text { решений по водо- } \\
\text { забору, транспор- } \\
\text { тирующей, рас- } \\
\text { пределительной и } \\
\text { отводящей сетей }\end{array}$ & $\begin{array}{l}\text { Обоснование и реа- } \\
\text { лизация улучшенных } \\
\text { параметров инженер- } \\
\text { ных решений }\end{array}$ & $\begin{array}{l}\text { Рациональные технические } \\
\text { и технологические решения }\end{array}$ \\
\hline $\begin{array}{l}\text { Энер- } \\
\text { гетиче- } \\
\text { ская }\end{array}$ & $\begin{array}{l}\text { Мускульная } \\
\text { энергия челове- } \\
\text { ка и животных }\end{array}$ & $\begin{array}{l}\text { Мускульная энер- } \\
\text { гия человека и } \\
\text { животных. Начало } \\
\text { использования } \\
\text { природных энер- } \\
\text { гетических ресур- } \\
\text { сов (воды, пара) }\end{array}$ & $\begin{array}{l}\text { Обоснование и реали- } \\
\text { зация улучшенных па- } \\
\text { раметров инженерных } \\
\text { решений. Использо- } \\
\text { вание механической и } \\
\text { электрической энер- } \\
\text { гий, а также энергии } \\
\text { воды и пара }\end{array}$ & $\begin{array}{l}\text { Рациональные технические } \\
\text { и технологические решения. } \\
\text { Использование энергии } \\
\text { солнца и ветра }\end{array}$ \\
\hline $\begin{array}{c}\text { Плани- } \\
\text { рова- } \\
\text { ния }\end{array}$ & $\begin{array}{l}\text { Интуиция че- } \\
\text { ловека и опыт } \\
\text { предшествую- } \\
\text { щих поколений }\end{array}$ & $\begin{array}{l}\text { Формирование } \\
\text { основ планиро- } \\
\text { вания }\end{array}$ & $\begin{array}{l}\text { Научное обоснование } \\
\text { и развитие методо- } \\
\text { логии планирования } \\
\text { при реализации } \\
\text { технологических } \\
\text { процессов }\end{array}$ & $\begin{array}{l}\text { Совершенствование тех- } \\
\text { нологий планирования с } \\
\text { использованием современ- } \\
\text { ных достижений научно-тех- } \\
\text { нического прогресса (АСУ, } \\
\text { АСУТП, ГИС) }\end{array}$ \\
\hline $\begin{array}{l}\text { Управ- } \\
\text { ления }\end{array}$ & $\begin{array}{l}\text { Интуиция че- } \\
\text { ловека и опыт } \\
\text { предшествую- } \\
\text { щих поколений }\end{array}$ & $\begin{array}{l}\text { Формирование } \\
\text { основ управленче- } \\
\text { ских решений }\end{array}$ & $\begin{array}{l}\text { Научное обоснование } \\
\text { и развитие систем } \\
\text { управления с исполь- } \\
\text { зованием информа- } \\
\text { ционно-советующих } \\
\text { систем (ИСС) } \\
\end{array}$ & $\begin{array}{l}\text { Совершенствование тех- } \\
\text { нологий управленческих } \\
\text { решений на основе исполь- } \\
\text { зования современных дости- } \\
\text { жений научно- технического } \\
\text { прогресса (НТП). }\end{array}$ \\
\hline $\begin{array}{c}\text { Взаи- } \\
\text { модей- } \\
\text { ствия } \\
\text { с при- } \\
\text { родной } \\
\text { средой }\end{array}$ & $\begin{array}{l}\text { Приспособление } \\
\text { к условиям при- } \\
\text { родной среды }\end{array}$ & $\begin{array}{l}\text { Интуитивное } \\
\text { использование } \\
\text { условий природ- } \\
\text { ной среды }\end{array}$ & $\begin{array}{l}\text { Осознание наличия } \\
\text { проблемы сохранения } \\
\text { природной среды. На- } \\
\text { учное обоснование и } \\
\text { разработка методоло- } \\
\text { гии взаимодействия с } \\
\text { природной средой. }\end{array}$ & $\begin{array}{l}\text { Совершенствование мето- } \\
\text { дологии взаимодействия } \\
\text { человека с природной сре- } \\
\text { дой с использованием совре- } \\
\text { менных достижений НТП } \\
\text { (система мониторингов, } \\
\text { создание международных } \\
\text { организаций по охране окру- } \\
\text { жающей природной среды) }\end{array}$ \\
\hline
\end{tabular}

В аспекте сказанного, мелиоративная система (в том числе и оросительная) - сложный природно-технический комплекс, составная часть 
агроландшафта, обеспечивающий регулирование кругооборота воды, вещества, энергии и информации в его границах. В процессе функционирования обеспечивается оперативное управление мелиоративными режимами орошаемых и осушаемых земель в режиме оптимизации с целью получения научно обоснованных, экономически целесообразных урожаев сельскохозяйственных культур; сохранения и повышения плодородия почв; обеспечения нормального мелиоративного состояния земель; надёжного технического состояния сооружений и всего оборудования, при обязательных условиях сохранения окружающей природной среды и создания цивилизованных условий для производственной и трудовой деятельности сельского населения [9].

Данный методологический подход даёт возможность рассматривать систему как многофакторную, замкнутую с регулируемыми антропогенными воздействиями на природную среду, что позволило разработать модель оросительной системы как объекта управления с учётом экологических требований и воздействий на неё природных и управляемых факторов, а также факторов оптимизации $[4,5,18,19]$. Выходными параметрами деятельности оросительной системы являются критерии оптимизации: урожайность, плодородие почв, эрозия, сбросы, фильтрация, загрязнение окружающей среды (рисунок 1).

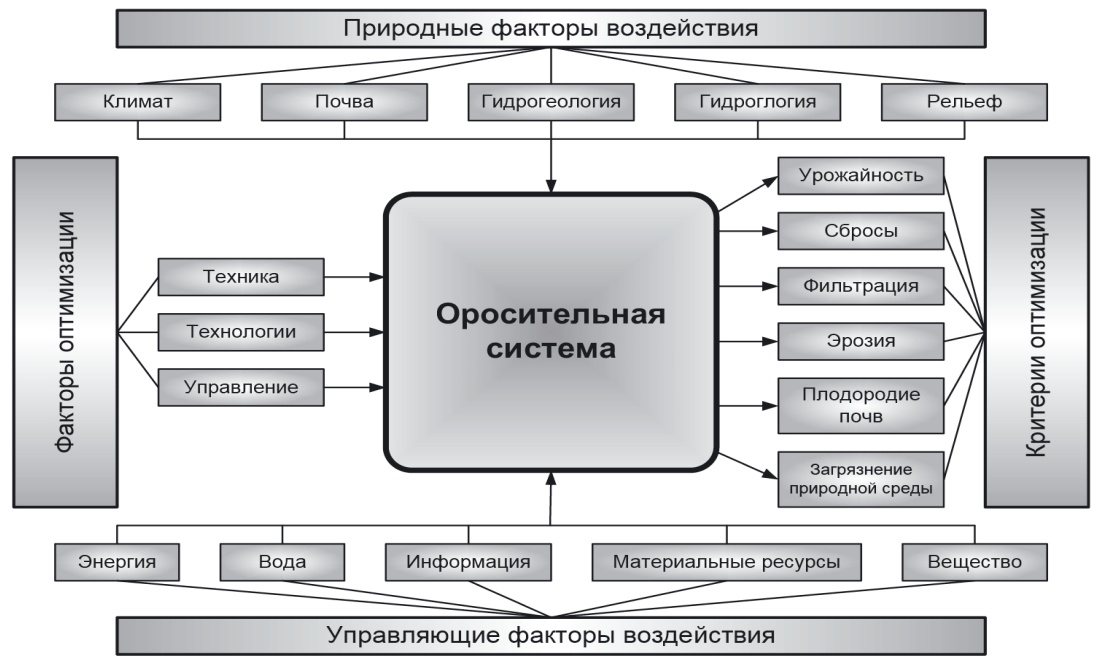

Рис. 1. Модель оросительной системы как объекта управления с учётом экологических требований 
Развитие кибернетики - науки об управлении сложными системами, внесло существенный вклад в перестройку системы управления технологическими процессами на мелиоративных системах и прежде всего в управленческой деятельности, в которой используется одна из прикладных ветвей кибернетики - системный анализ. В основе разработки и реализации указанной методологии находится понятие «системы» и прежде всего «большой» или «сложной системы» [8]. Проведенный анализ показывает, что мелиоративной системе присущи признаки «больших» или «сложных систем» (рисунок 2), что позволило обосновать новый методологический подход к их функционированию (рисунок 3 ).

Системный анализ - методика исследования любых объектов посредствам представления их в качестве систем и анализ этих систем

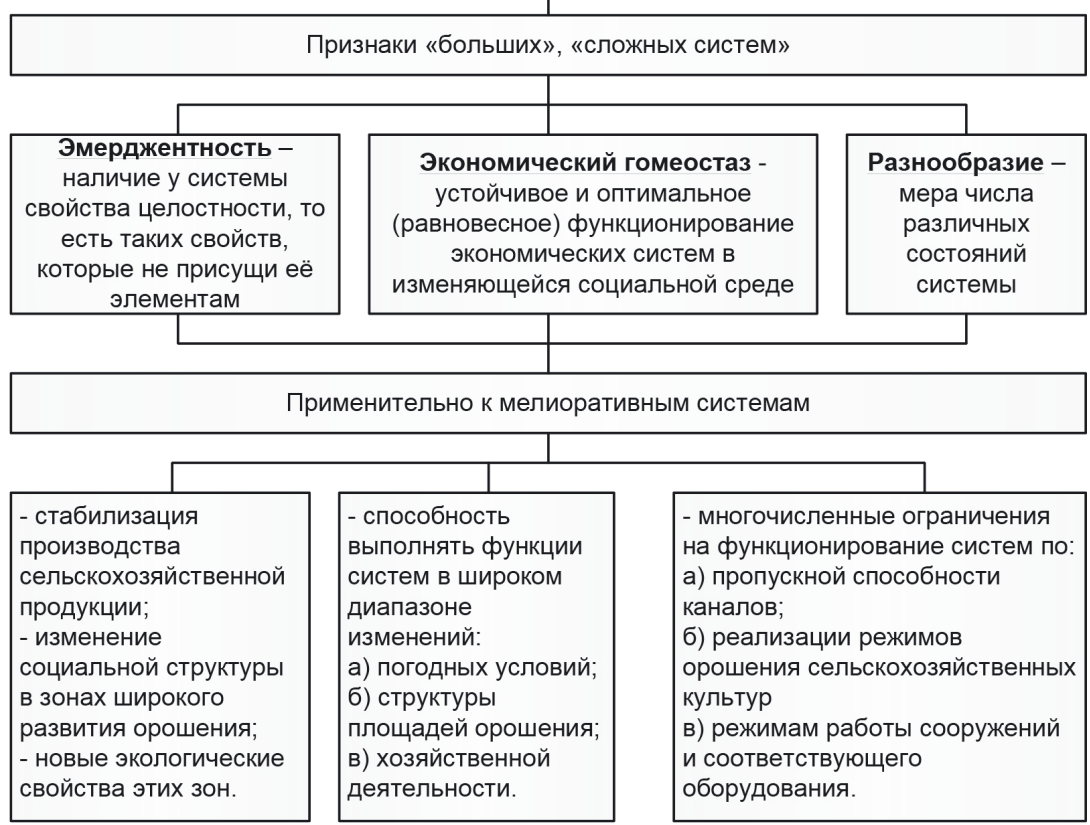

Рис. 2. Признаки «больших», «сложных систем»

Повышение эффективности орошения в целом на оросительных системах решается на двух уровнях: первый - хозяйства или отдельные водопользователи; второй - управления оросительных систем. В хозяйствах 
(водопользователях) эту проблему решают поиском экономически целесообразных режимов орошения сельскохозяйственных культур, установлением оптимальной структуры посевных площадей, оптимизацией распределения всех видов ресурсов между полями орошения при обязательном условии достаточной рентабельности производства в конкретно сложившихся условиях хозяйствования [9].

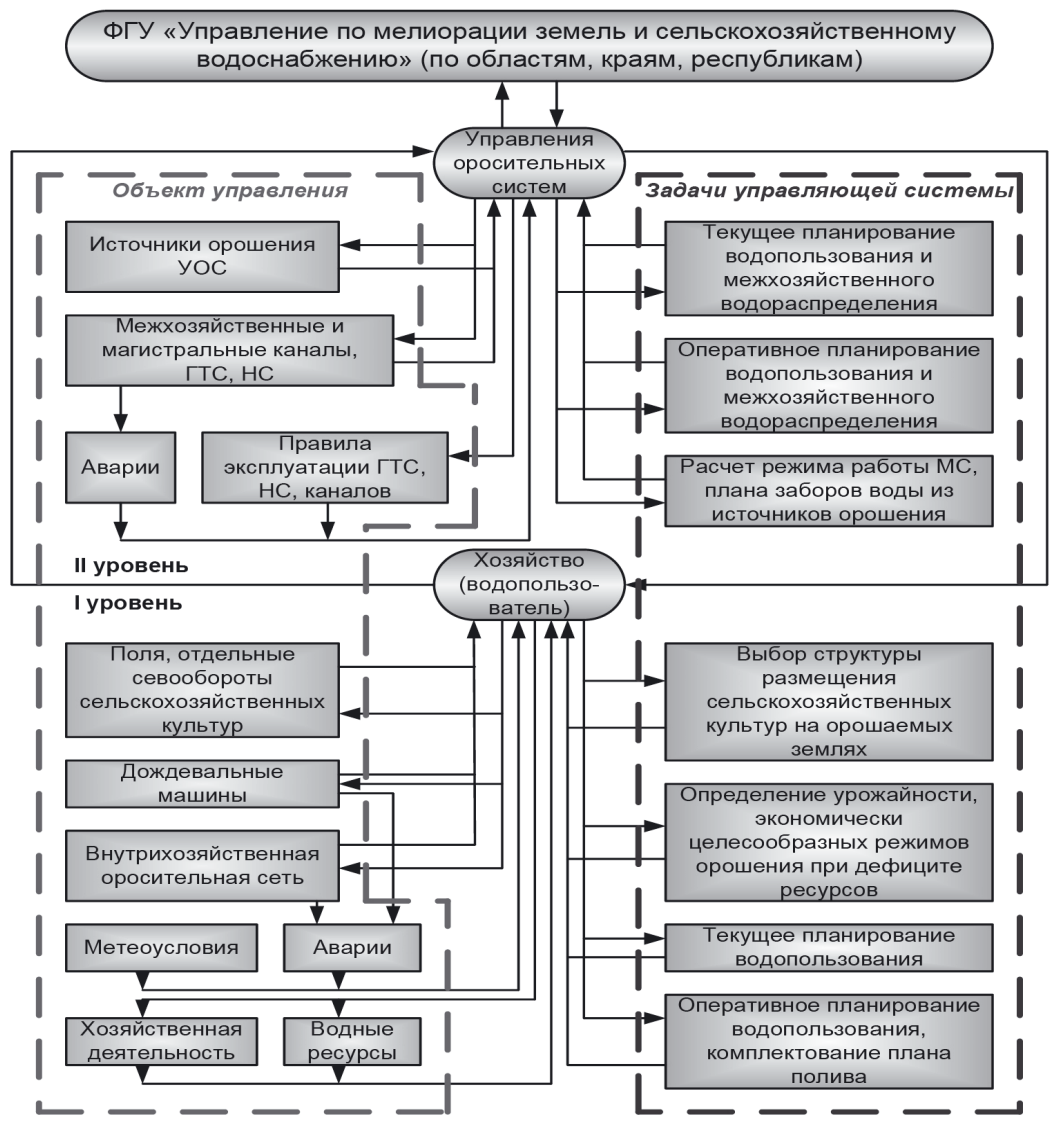

Рис. 3. Двухуровневая система управления оптимизацией водопользования на оросительных системах.

В управлениях оросительных систем указанную проблему решают за счёт оптимизации распределения водных ресурсов между потребителя- 
ми, с использованием методов системного анализа, имитационного моделирования, экономико-математических методов, нелинейного динамического программирования, диалогового взаимодействия эксперта с ЭВМ [10, 11$]$. Следует отметить что, эффективность управления технологическими процессами на системах зависит от полноты, объективности и оперативности обработки и реализации получаемой информации $[4,20]$. С этой целью разработана соответствующая классификация, необходимая для оперативного планирования и управления орошением, включающая информационно-справочную, сезонную и оперативную информацию. Совершенствование процесса планирования и управления орошением обеспечивается моделью прогноза, состоящей из блоков управления информационной базой и пространственно-временной оптимизации. Блок управления состоит из подблоков прогнозирования динамики влагозапасов, режимов орошения и их оптимизации при дефиците ресурсов [4, 8, 12].

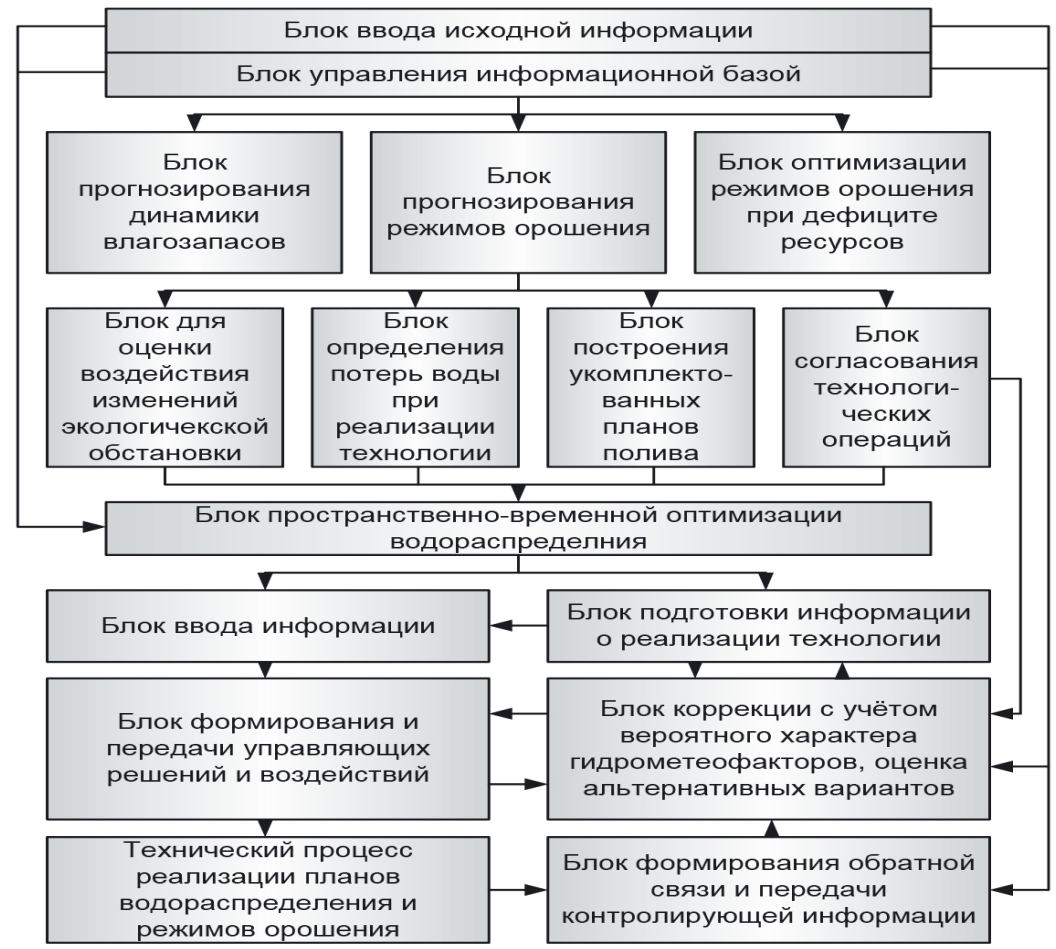

Рис. 4. Модель прогноза планирования и оперативного управления поливами 
Блок пространственно-временной оптимизации включает подблоки ввода информации, формирования и передачи управляющих решений и воздействий, корректировки и оценки ошибок с учётом вероятностного характера гидрометеорологических факторов. Основные блоки связанны между собой через подблоки формирования обратной связи и согласования технических операций (рисунок 4). Методы системного анализа реализованы также при планировании и оперативном управлении водопользованием и водораспределением на оросительных системах Северного Кавказа $[10,11]$. Сущность метода заключается в расчленении общей задачи планирования и оперативного управления на ряд взаимоувязанных подзадач через управляющие переменные, в независимом решении этих задач и последующей координацией решения по каждому блоку с целью получения оптимизированных результирующих показателей, которые принимает эксперт.

Блочная структура планирования водопользования на оросительной системе показана на рисунке 5.

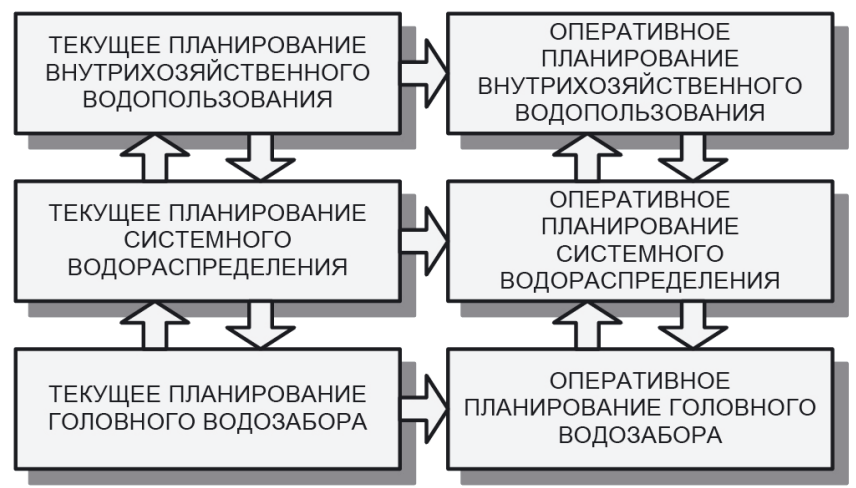

Рис. 5. Блочная структура планирования водопользования

Оптимальное водораспределение формируется по наиболее эффективному варианту (не исключая, конечно, правомерности других вариантов) с определением экономически целесообразных режимов орошения сельскохозяйственных культур на основе сочетания водно-балансовой концепции с экономическими критериями оценки решений о назначении поливов [3, $10,15,16]$. Приемлемый режим орошения выбирают, привлекая специалистов, по результатам комплексного анализа основных экономических показателей: валового сбора, размеров мелиоративных и сельскохозяйственных 
затрат, уровня рентабельности, объёма водопотребления, прибыли на 1 м поданной воды или на 1 т продукции. Имитационная модель расчёта экономически целесообразных режимов орошения сельскохозяйственных культур имеет блочную структуру и приведена на рисунке 6.

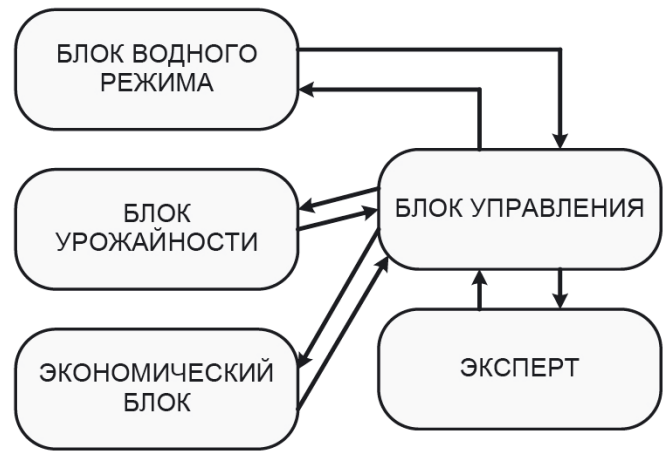

Рис. 6. Модель расчёта экономически целесообразных режимов орошения сельскохозяйственных культур

Системный подход в решении вопросов водопользования позволяет также разрабатывать имитационные модели по определению оптимальной структуры сельскохозяйственных культур, их площадей и размещения, а также модели по определению объективных цен на продукцию растениеводства как по хозяйствам, так и по более мелким подразделениям, которые позволяют в режиме деловой игры, меняя значения одних управляющих параметров, получать оптимальные значения других (рентабельность, договорные цены, тарифы на оросительную воду в сложившихся условиях хозяйствования и соответствующие режимы орошения).

\section{Результаты}

Широкая апробация разработанных моделей была проведена на оросительных системах Ростовской области и республики Дагестан.

Мелиоративные системы, являясь составной частью агроландшафта, должны быть прежде всего экологически сбалансированными, надёжными, то есть сохранять экологическое равновесие в установленных пределах в течении длительного времени.

Функционирование мелиоративных систем в указанном режиме обусловливают необходимость установления и изучения всех факторов, влияющих на экологическую надёжность систем, то есть способность 
систем сохранять все установленные экологические показатели, которые разделяются на объективные и субъективные.

Использование указанных выше методологических подходов позволило разработать функциональную структуру комплекса задач управления технологическими процессами на оросительной системе, которая включает восемь блоков: водопользование, водораспределение, техническое, агроклиматическое и мелиоративное состояние объекта, технологическую карту, правовое и экологическое обоснование.

Эти блоки функционируют во взаимосвязи, в едином комплексе технологического процесса: календарное и оперативное планирование, оперативное управление в режиме автоматизации, сбор и анализ полученных данных с последующим учётом результатов и внесением необходимых корректировок в соответствующие элементы технологических процессов.

\section{Заключение}

Разработанная функциональная структура является базовой при планировании, корректировке и оперативном управлении водопользованием и прошла широкую производственную апробацию на оросительных системах Северного Кавказа. Таким образом, научное обоснование, разработка и реализация технологий экологически сбалансированных мелиоративных систем обеспечивают значительный прогресс в мелиоративной науке и практике, устойчивость производства сельскохозяйственной продукции и сохранение окружающей природной среды.

\section{Список литературы}

1. Ольгаренко В.И. Современная концепция эксплуатации оросительных систем / В.И. Ольгаренко, Г.В. Ольгаренко // Мелиорация и водное хозяйство. 1999. № 2. С. 21-22.

2. Половинкин А.И. Основы инженерного творчества. М: Машиностроение, 1986. $326 \mathrm{c}$.

3. Ольгаренко В.И. Анализ конструкций гидромелиоративных систем на основе законов стадийного развития техники / В.И. Ольгаренко, Г.В. Ольгаренко // Мелиорация и водное хозяйство. 1998. № 1. С. 23-26.

4. Ольгаренко В.И., Ольгаренко Г.В., Рыбкин Г.В. Эксплуатация и мониторинг мелиоративных систем: учебник для высших учебных заведений. Коломна: Инлайт, 2006. 391 с.

5. Израэль Ю.А. Экология и контроль состояния природной среды: 2-е изд. М.: Гидрометеоиздат, 1984. 560 с. 
6. Кирейчева Л.В. Значение комплексных мелиораций для формирования продуктивности и устойчивости агроландшафтов / Л.В. Кирейчева, И.В. Белова // Мелиорация и водное хозяйство. 2004. № 4. С. 23-25.

7. Юрченко И.Ф. Эксплуатационный мониторинг мелиоративных систем для поддержки управленческих решений // Мелиорация и водное хозяйство. 2004. № 4. С. 48-52.

8. Ольгаренко В.И. Экологически устойчивые мелиоративные системы / В.И. Ольгаренко, И.В. Ольгаренко // Труды Кубанского гос. аграрного унта. 2009. № 6. С. 205-209.

9. Ольгаренко В.И. Экологические проблемы ирригации и дренажа в аридной зоне / В.И. Ольгаренко, Г.В. Ольгаренко, И.В. Ольгаренко // 55 сессия Международного исполнительного комитета МКИД. М.: 2004. С. 36-41.

10. Ольгаренко И.В. Оценка качества планирования и реализации водопользования на оросительных системах // Вестник Россельхозакадемии. 2009. № 4. С. 35-37.

11. Ольгаренко В.И. Технико-экономические показатели водопользования на оросительных системах // Природопользование. 2009. № 4. С. 102-106.

12. Ольгаренко Г.В. Стратегия научно-технической деятельности по разработке новой техники для орошения при реализации программы развития мелиорации // Мелиорация и водное хозяйство. 2011. № 6. С. 5-8.

13. Ольгаренко Г.В. Методические указания по применению технологий и техники синхронного импульсного дождевания при реконструкции и модернизации оросительных систем / Г.В. Ольгаренко, С.С. Турапин, А.А. Терпигорев, С.А. Гжибовский. Коломна: 2016.44 с.

14. Ольгаренко Г.В. Проблемы и перспективы технического обеспечения орошения // Мелиорация и водное хозяйство. 2010, № 2. С. 8-10.

15. Ковалев Н.Г. Методы и критерии диагностики и оценки состояния осушительных систем / Н.Г. Ковалев, Г.В. Ольгаренко, Ю.И. Митрофанов [и др.]. Коломна: 2015, 36 с.

16. Faubert Jean-Pascal R., Carey Sean K. Growing season water balance of wetland reclamation test cells, Fort McMurray, Alberta. Ottawa: 2014, 128 p. Available: http://agris.fao.org/agris-search/search.do?recordID=US201400150552

17. Shkutov Eh.N.. Luchenok L.N.. Ivanov V.P. Research of the possibility of drainage and effective agricultural use system rehabilitation, removed of exclution and resettlement zone. Minsk: 2012, pp. 73-90. Available: http://agris.fao.org/agrissearch/search.do?recordID=BY2012000533

18. Zainal Khadija, Al-Madany Ismail, Al-Sayed Hashim, Khamis Abdelqader [and others]. The cumulative impacts of reclamation and dredging on the marine 
ecology and land-use in the Kingdom of Bahrain. 2012, 1452-1458 pp. Available: http://www.sciencedirect.com/science/article/pii/S0025326X12001567

19. Zhao Zhongqiu, Shahrour Isam, Bai Zhongke [and others]. Soils development in opencast coal mine spoils reclaimed for 1-13 years in the West-Northern Loess Plateau of China. European Journal of Soil Biology, V. 55, 2013, pp. 40-46. Available: http://www.sciencedirect.com/science/article/pii/S1164556312000842

20. Vera L., Martel G., Márquez M., Two years monitoring of the natural system for wastewater reclamation in Santa Lucía, Gran Canaria Island. Ecological Engineering, V. 50, 2013. pp. 21-30. Available: http://www.sciencedirect.com/science/article/pii/S0925857412002613

\section{References}

1. Ol'garenko V.I., Ol'garenko G.V. Sovremennaya kontseptsiya ekspluatatsii orositel'nykh system [The modern concept of operation of irrigation systems]. Melioratsiya i vodnoe khozyaystvo [Melioration and water management]. 1999, №2, pp. 21-22.

2. Polovinkin A.I. Osnovy inzhenernogo tvorchestva [The fundamentals of engineering creativity]. Moscow: Mashinostroenie Publ., 1986, 326 p.

3. Ol'garenko V.I., Ol'garenko G.V. Analiz konstruktsiy gidromeliorativnykh sistem na osnove zakonov stadiynogo razvitiya tekhniki [The Analysis of the constructions of hydro-meliorative systems based on the laws of stepwise development of technics]. Melioratsiya $i$ vodnoe khozyaystvo [Melioration and water management]. 1998, № 1, pp. 23-26.

4. Ol'garenko V.I., Ol'garenko G.V., Rybkin G.V. Ekspluatatsiya i monitoring meliorativnykh sistem: uchebnik dlya vysshikh uchebnykh zavedeniy [The operation and monitoring of melioration systems: the manual for a higher educational institution]. Kolomna: Inlayt Publ., 2006, 391 p.

5. Izrael' Yu.A. Ekologiya i kontrol' sostoyaniya prirodnoy sredy [The Ecology and the control of the natural environment: 2nd ed.]. Moscow: Gidrometeoizdat Publ., 1984, 560 p.

6. Kireycheva L.V., Belova I.V. Znachenie kompleksnykh melioratsiy dlya formirovaniya produktivnosti i ustoychivosti agrolandshaftov [The value of complex reclamation for the formation of productivity and sustainability of agrolandscapes]. Melioratsiya $i$ vodnoe khozyaystvo [Melioration and water management ]. 2004, № 4, pp. 23-25.

7. Yurchenko I.F. Ekspluatatsionnyy monitoring meliorativnykh sistem dlya podderzhki upravlencheskikh resheniy [The Operational monitoring of melioration systems to support management decisions]. Melioratsiya $i$ vodnoe khozyaystvo [Melioration and water management]. 2004, № 4, pp. 48-52. 
8. Ol'garenko V.I., Ol'garenko I.V. Ekologicheski ustoychivye meliorativnye sistemy [Environmentally sustainable reclamation systems]. Trudy Kubanskogo gos. agrarnogo universiteta [Proceed. of Kuban state agrarian university] 2009, № 6, pp. 205-209.

9. Ol'garenko V.I., Ol'garenko G.V., Ol'garenko I.V. Ekologicheskie problemy irrigatsii i drenazha $\mathrm{v}$ aridnoy zone [The ecological problems of irrigation and drainage in arid zone]. 55 sessiya Mezhdunarodnogo ispolnitel'nogo komiteta MKID [55 session of International commission of irrigation and drainage]. Moscow: 2004, pp. 36-41.

10. Ol'garenko I.V. Otsenka kachestva planirovaniya i realizatsii vodopol'zovaniya na orositel'nykh sistemakh [The evaluation of the quality of planning and implementation of water use in irrigation systems]. Vestnik Rossel'khozakademii [Bulletin of the Russian Academy of Agricultural Sciences]. 2009, № 4, pp. 35-37.

11. Ol'garenko V.I., Ol'garenko I.V. Tekhniko-ekonomicheskie pokazateli vodopol'zovaniya na orositel'nykh sistemakh [Technical and economic parameters of water use in irrigation systems]. Prirodopol'zovanie [Nature management]. 2009, № 4, pp. 102-106.

12. Ol'garenko G.V. Strategiya nauchno-tekhnicheskoy deyatel'nosti po razrabotke novoy tekhniki dlya orosheniya pri realizatsii programmy razvitiya melioratsii [The strategy of the scientific and technical activity of the development of new technique for irrigation in the implementation of land reclamation program]. Melioratsiya $i$ vodnoe khozyaystvo [Melioration and water management]. 2011, № 6, pp. 5-8.

13. Ol'garenko G.V., Turapin S.S., Terpigorev A.A., Gzhibovsky S.A. Metodicheskie ukazaniya po primeneniyu tehnologii i tehniki sinhronnogo impulsnogo dojdevania pri reconstrukcii i modernizacii orositel'nih sistem [Guidelines for the use of technology and technology synchronous impulse irrigation in the reconstruction and modernization of irrigation systems]. Kolomna: 2016, 44 p.

14. Ol'garenko G.V. Problemi i perspectivi tehnicheskogo obespechenia orosheniya [Problems and prospects of technical support for irrigation]. Melioratsiya $i$ vodnoe khozyaystvo [Melioration and water management]. 2010, № 2, pp. 8-10.

15. Kovalev N.G., Olgarenko G.V., Mitrofanov Yu.I., Zinkovsky V.N., Petrova L.I., Panteleeva T.N. Metodi i kriterii diagnostiki i ocenki sostoyaniya osushitel'nih sistem [Methods and criteria for diagnosis and assessment of drainage systems]. Kolomna: 2015, 36 p.

16. Faubert Jean-Pascal R., Carey Sean K. Growing season water balance of wetland reclamation test cells, Fort McMurray, Alberta. Ottawa: 2014, 128 p. http://agris. fao.org/agris-search/search.do?recordID=US201400150552 
17. Shkutov Eh.N., Luchenok L.N., Ivanov, V.P. Research of the possibility of drainage and effective agricultural use system rehabilitation, removed of exclution and resettlement zone. Minsk: 2012, pp. 73-90. http://agris.fao.org/agrissearch/search.do?recordID=BY2012000533

18. Zainal Khadija, Al-Madany Ismail, Al-Sayed Hashim, Khamis Abdelqader [and others]. The cumulative impacts of reclamation and dredging on the marine ecology and land-use in the Kingdom of Bahrain. 2012, 1452-1458 pp. http://www.sciencedirect.com/science/article/pii/S0025326X12001567

19. Zhao Zhongqiu, Shahrour Isam, Bai Zhongke [and others]. Soils development in opencast coal mine spoils reclaimed for 1-13 years in the West-Northern Loess Plateau of China. European Journal of Soil Biology, V. 55, 2013, pp. 40-46. http://www.sciencedirect.com/science/article/pii/S1164556312000842

20. Vera L., Martel G., Márquez M., Two years monitoring of the natural system for wastewater reclamation in Santa Lucía, Gran Canaria Island. Ecological Engineering, V. 50, 2013, pp. 21-30. http://www.sciencedirect.com/science/article/pii/S0925857412002613

\section{ДАННЫЕ ОБ АВТОРАХ}

Ольгаренко Владимир Иванович, доктор технических наук, профессор, член-корреспондент РАН, профессор кафедры «Техносферная безопасность, мелиорация и природообустройство»

Новочеркасский инженерно-мелиоративный институт, филиал Федерального государственного бюджетного образовательного учреждения высшего образования Донской государственный аграрный университет

ул. Пушкинская, 111, г. Новочеркасск, Ростовская обл., 346428 , Российская Федерачия danel777888@mail.ru

Ольгаренко Игорь Владимирович, доктор технических наук, доцент, профессор кафедры «Техносферная безопасность, мелиорация и природообустройство»

Новочеркасский инженерно-мелиоративный институт, филиал Федерального государственного бюджетного образовательного учреждения высшего образования Донской государственный аграрный университет

ул. Пушкинская, 111, г. Новочеркасск, Ростовская обл., 346428, Российская Федеращия danel777888@mail.ru 
Ольгаренко Владимир Игоревич, кандидат технических наук, научный сотрудник отдела «Управление продуктивностью орошаемых агробиоценозов»

Российский научно-исследовательский институт проблем мелиорачии

пр. Баклановский, 190, г. Новочеркасск, Ростовская обл., 346400 , Российская Федерация

olgarenko_vi@mail.ru

\section{DATA ABOUT AUTHORS}

Olgarenko Vladimir Ivanovich, Doctor of Technical Sciences, Professor, Corresponding Member of the Russian Academy of Sciences, Professor of the Department «Technosphere Safety, Reclamation and Environmental Engineering»

Novocherkassk Engineering and Land Reclamation Institute of Don State Agrarian University

111, Pushkinskaya Str., Novocherkassk, Rostov Region, 346428, Russian Federation

danel777888@mail.ru

Olgarenko Igor Vladimirovich, Doctor of Technical Sciences, Docent, Professor of the Department «Technosphere Safety, Reclamation and Environmental Engineering»

Novocherkassk Engineering and Land Reclamation Institute of Don State Agrarian University

111, Pushkinskaya Str., Novocherkassk, Rostov Region, 346428, Russian Federation danel777888@mail.ru

Olgarenko Vladimir Igorevich, Candidate of Technical Sciences, Researcher at the Department of «Management of Productivity of Irrigated Agrobiocenoses»

Russian Scientific Research Institute of Land Improvement Problems 190, Baklanovsky Ave., Novocherkassk, Rostov Region, 346400, Russian Federation

olgarenko_vi@mail.ru 